\title{
Prevalence, Antibiogram Pattern and Virulence Genes Profile of Bacillus cereus Isolated from Buffalo Milk
}

\author{
Hussien A Abouelhag*, Eman A Khairy, Hanan Sh Marie and Doaa D Khalaf \\ Microbiology and Immunology, National Research Centre, 33 Bohouth st., Dokki, Cairo, Postal code 12622, Egypt \\ *Corresponding author: migris410@gmail.com
}

\begin{abstract}
Article History: 20-254 Received: 31-Dec-2020 $\quad$ Revised: 18-Jan-2021 $\quad$ Accepted: 29-Jan-2021
\section{ABSTRACT}

In Egypt, the buffalo's milk is greatly consumed on a large population scale, due to its nutrition quality and palatability, so there is a needing to ensure its microbiological quality especially for food borne pathogens to be safe for human consumption. The current study was conducted on a total of 85 solitary collected raw buffalo's milk samples at El- Giza Governorate. The cultural examination revealed that Bacillus cereus was isolated in 11 samples by (12.94\%). The biochemical examination of the 11 isolates exhibited predominant two different biotypes 2 and 5 . The antibiogram manner exposed that all isolates were sensitive to gentamicin, neomycin and ciprofloxacin, less sensitive to tetracycline $(87.5 \%)$ vancomycin $(81.25 \%)$ and erythromycin $(81.25 \%)$, intermediate to ampicillin $(56.25 \%)$ and polymyxin $(43.75 \%)$ while the eleven isolates were resistant to both amoxicillin and penicillin $\mathrm{G}$ (100\%). The multiplex PCR was carried out to assess conservative gene $16 \mathrm{~S}$ rDNA gene, ces (cereulide encoding gen) and entFM (enterotoxin-encoding gene) among the eleven isolates. The procured data demonstrated that only ten isolates amplified the targeted 16S rDNA product $964 \mathrm{bp}(90.9 \%)$. On the other side, there were six isolates showed amplicons of average molecular size 486 bp (54.54\%) while two isolates amplified $1271 \mathrm{bp}(18.18 \%)$, which targeted ent $\mathrm{FM}$ and ces respectively. The obtained data proposed that raw buffalo's milk may considered a source of public health concern toxigenic $B$. cereus which may be implemented in food-borne illness.
\end{abstract}

Key words: Bacillus cereus, Toxigenic \& Resistance genes, Buffalo's Milk, PCR, Antibiotic Susceptibility (C202 I IJVS - All Rights Reserved

\section{INTRODUCTION}

Bacillus cereus is an aerobic spore-forming, rodshaped and motile bacterium, positive to Gram stain, commonly implemented in the dairy products deterioration. The microorganism possesses a property of adherence to the dairy stainless-steel equipment as well as the ability to produce various types of toxins; cytotoxic, vomiting inducer and enterotoxins. So, it constitutes a significant risk to health as regarding food poisoning (Lucking et al. 2013; Majed et al. 2016; Hussain et al. 2018). Even if unsuitable environment exists, the organism can produce spores waiting the conditions become favorable; germination of spores during cooling process of dairy products boosting the bacteria to grow and secrete their toxins (Liu et al. 2020). Moreover, because of the spore-forming and the psychotropic leaning of the organism; survival and multiplication of $B$. cereus during milk processing, resulting in usual reported food poisoning cases (Kumari and Sarkar 2016).
Generally, B. cereus food infection and intoxication occupied a leading rank among the organisms causing foodborne outbreaks that reported worldwide, (Haque et al. 2021), but unfortunately; in Egypt, there were scarce reports and data about the presence of B. cereus among the dairy foodstuff (Abdou et al. 2011; Sadek et al. 2018; Al-Gamal et al. 2019).

There are various species of genus Bacillus, of which many of them may similar in morphological, cultural and biochemical appearance. So, their differentiation may rely on the molecular structural genes profile; $16 \mathrm{~S}$ rDNA is considered an important conservative gene implemented in differential molecular diagnosis of bacterial species (Giffel et al. 1997; Mousa and Marwan 2019).

B. cereus is considered an opportunistic organism commonly result in two different conditions of food poisoning in human being; the first is manifested by nausea and vomiting, while the other is associated with abdominal pain and diarrhea (Osimani et al. 2018).

Cite This Article as: Abouelhag HA, Khairy EA, Marie HS and Khalaf DD, 2021. Prevalence, antibiogram pattern and virulence genes profile of Bacillus cereus isolated from buffalo milk. International Journal of Veterinary Science 10(3): 234-239. https://doi.org/10.47278/journal.ijvs/2021.045 
Interestingly, the B. cereus food poisoning is unique as both the organism and its toxins able to induce the disease. Cereulide is a greatly stable toxin; resist heat, drastic $\mathrm{pH}$ conditions and protease activities. Once performed in food, this toxin cannot be inactivated either during processing or in alimentary tract; so, it can induce serious food intoxication illness even when the organism is not present or killed (Kranzler et al. 2016).

Otherwise, the diarrheal form is a food infection; induced by ingestion of food contaminated by viable vegetative bacterial cells not their preformed toxins. When, the organism reaches small intestine, it can secret many types of enterotoxins, leads to induction of diarrhea (Jeßberger et al. 2017).

The previous illness conditions are attributed to the virulence genes subsequently virulence toxins produced by $B$. cereus. The vomiting form is induced by heat stable toxin named 'cereulide', which is encoded by cereulide synthethase (ces) gene. On the other hand, the diarrheal status is persuaded via production of many enterotoxins, one of them is called enterotoxin FM which encoded by ent FM gene (Forghani et al. 2016).

Taking in consideration the above circumstances, the study targeted the prevalence, identification, antibiogram, and spotlighted important virulence genes of B. cereus among raw buffalo milk in Giza city.

\section{MATERIALS AND METHODS}

\section{Sampling}

An overall 85 raw buffalo's milk samples were collected from farmers and markets at El-Giza Governorate during 2019. The obtained samples were transmitted to the microbiology laboratory in cooled, insulated sterile plastic bags under aseptic condition.

\section{Isolation and Biochemical Identification of B. Cereus}

A loopful from each milk sample was streaked on plates contained $B$. cereus mannitol yolk polymyxin B agar (Himedia, India). Plates were incubated for $24 \mathrm{~h}$, at $30^{\circ} \mathrm{C}$ and monitored for growth; the suspected colonies were picked up, Gram's stained and inspected microscopically before being streaked into semisolid and slope agar for preservation and further biochemical identification. Biochemical identification of B. cereus was performed according to Bacteriological Analytical Manual; via TSI test, catalase, urease and nitrate reduction tests (Rhodehamel and Harmon 2001).

\section{Biotyping}

The obtained isolates were biotyped relying on their capability to ferment ammonium salt sugars (ASS), namely, cellobiose, salicin and xylose, as per the scheme planned by Jha and Narayan (1995).

\section{Antimicrobials Susceptibility Testing}

Sensitivity versus antibiotics' resistance profile of $B$. cereus isolates were checked via Mueller-Hinton agar (Himedia) using disc diffusion method proposed by the Clinical and Laboratory Standards Institute guidelines (CLSI 2015). The following antibiotic discs (Sigma) (indicate manufacturer and reference) were used; penicillin $\mathrm{G}(10 \mu \mathrm{g})$, amoxicillin $(10 \mu \mathrm{g})$, ampicillin
$(10 \mu \mathrm{g})$, erythromycin $(15 \mu \mathrm{g}), \quad$ vancomycin $(3 \mu \mathrm{g})$, gentamycin $(10 \mu \mathrm{g})$, neomycin $(30 \mu \mathrm{g})$ ciprofloxacin $(5 \mu \mathrm{g})$, polymyxin $(10 \mu \mathrm{g})$ and tetracycline $(30 \mu \mathrm{g})$. Susceptibility categorization was carried out according to standards guiding antimicrobial disc sensitivity tests (CLSI 2018).

\section{Genomic DNA Extraction and PCR Assay DNA Extraction}

The standard strains Bacillus cereus (ATCC 14579) and Staphylococcus aureus (ATCC 25923) were used for positive and negative standard respectively. The mentioned strains were purchased from the reference laboratory of the Cairo Microbiological Resources Center (Cairo MIRCEN), Faculty of Agriculture, Ain-Shams University.

DNA was extracted from B. cereus isolates and the standard strains using the QIAamp DNA Mini kit (Qiagen, Germany, GmbH) after amendments manufacturer's guidelines. Briefly, $200 \mu$ l of the sample suspension was incubated with $10 \mu \mathrm{l}$ of proteinase $\mathrm{K}$ and $200 \mu \mathrm{l}$ of lysis buffer at $56^{\circ} \mathrm{C}$ for $10 \mathrm{~min}$. After incubation, $200 \mu \mathrm{l}$ of $100 \%$ ethanol was added to the lysate. After that the sample was washed and centrifuged keeping the manufacturer's recommendations and nucleic acid was eluted with $100 \mu$ l of elution buffer provided in the kit.

\section{PCR Detection of Structural and Virulence Genes}

PCR screening was performed to determine the existence of a conservative gene (16S rDNA gene) and two other virulence genes; (ces) which are responsible for production of emetic cereulide toxin and (ent $\mathrm{FM})$ an enterotoxin-encoding gene.

The multiplex PCR of the three genes was carried out in a 50 $\mu 1$, PCR reaction containing $25 \mu 1$ of Emerald Amp Max PCR Master Mix (Takara, Japan), $1 \mu l$ of each primer of 20 pmol concentrations, $9 \mu 1$ of water, and $10 \mu 1$ of DNA template. The used primers were supplied from Metabion (Germany) and the amplification process was conducted in (Biometra, Germany) thermal cycler (Wehrle et al. 2009; Dzieciol et al. 2013) as described in the Table 2.

The PCR reaction mixtures were analyzed by electrophoresis on a $1.5 \%(\mathrm{w} / \mathrm{v})$ agarose gel in the presence of 100bp DNA ladder (Fermentas Life Science, EU) according to Sambrook et al. (1989).

\section{RESULTS}

Among 85 raw buffalo's milk samples solitary collected from farmers and markets at El- Giza Governorate, the cultural criteria revealed a number of 11 presumptive isolates with a rate of $12.94 \%$. Suspected $B$ cereus colonies exhibited pink look (mannitol-negative) surrounded by a precipitation zone (lecithinase positive).

The suspected $B$. cereus isolates produced catalase, reduced nitrate and ferment glucose, while the production of urease was achieved in seven isolates. The biotyping identification of $B$. cereus isolates declared that the predominating biotypes were 2 (7 isolates) and 5 (3 isolates) as shown in Table 1.

The antibiotic susceptibility manner to ten antimicrobials exposed that the B. cereus isolates were highly sensitive to gentamicin $(100 \%)$, neomycin $(100 \%)$, Ciprofloxacin $(100 \%)$, less sensitive to tetracycline $(87.5 \%)$, 


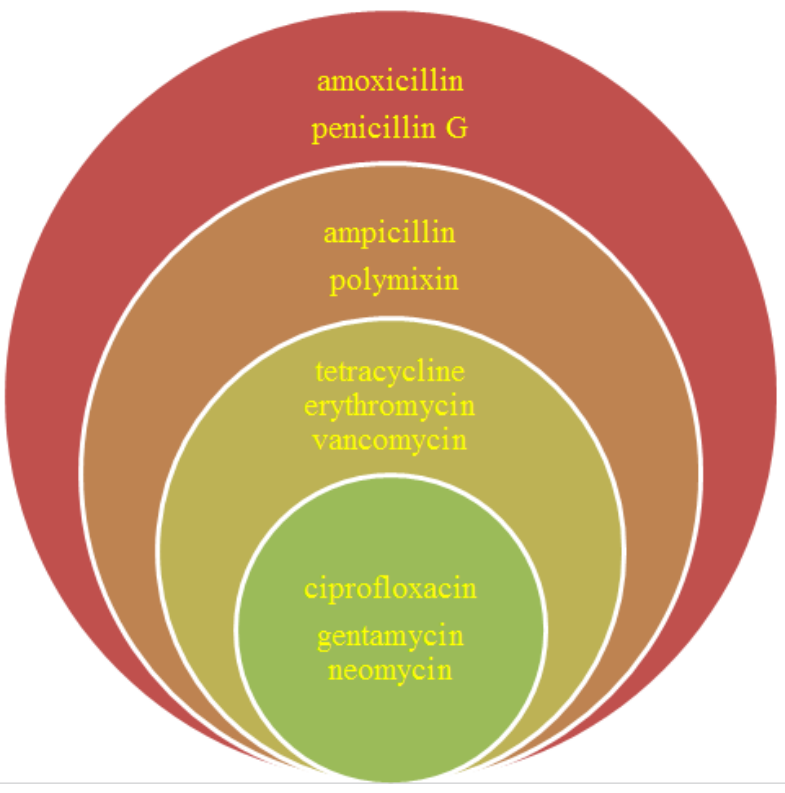

Fig. 1: diagram showing the sensitivity pattern of Bacillus cereus isolates to tested antibiotics; the green represented $100 \%$ sensitivity, light brown represented lesser sensitivity, dark brown represented intermediate sensitivity, while the red represented $100 \%$ resistance.

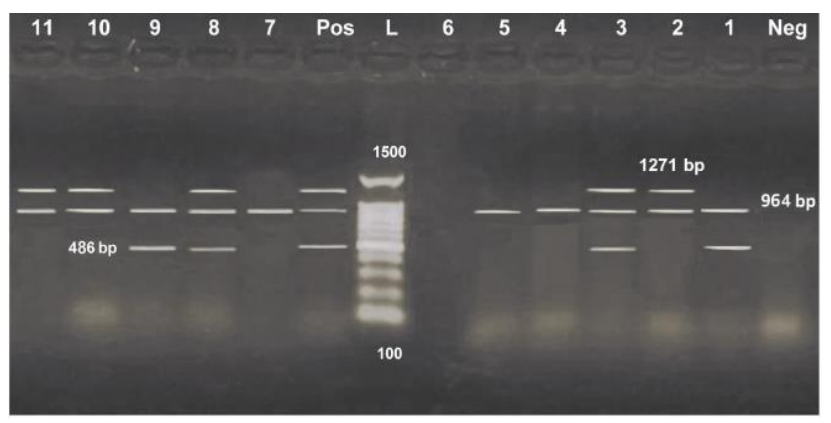

Fig. 2: Multiplex polymerase chain reaction; detection of structural and virulence genes in Bacillus cereus isolates. L: 100 bp DNA ladder. Lanes 1-11: Bacillus cereus isolates. Lane Pos: Positive control; amplification of 964 bp represented 165 rDNA, $486 \mathrm{bp}$ represented entFM, and 1271 bp represented ces. Lane Neg: Negative control.

Table 1: Biotyping scheme of Bacillus group as established by Jha and Narayan (1995)

\begin{tabular}{lccc}
\hline Biotype & Xylose & Salicin & Cellubiose \\
\hline 1 & - & - & - \\
2 & + & - & + \\
3 & - & + & - \\
4 & + & - & - \\
5 & + & + & + \\
6 & - & - & + \\
7 & - & + & + \\
8 & + & + & - \\
\hline
\end{tabular}

vancomycin (81.25\%), and erythromycin (81.25\%) intermediate to ampicillin $(56.25 \%)$ and polymyxin $(43.75 \%)$. On the other side, the isolates showed a great resistance against both penicillin G (100\%), and amoxicillin (100\%) as displayed in Fig. 1.

The multiplex PCR criteria for conservative $16 \mathrm{~S}$ rDNA gene, ces (cereulide encoding gen) and entFM (enterotoxin-encoding gene) was carried out on the eleven suspected $B$. cereus isolates.
The obtained data exhibited that only ten isolates amplified the targeted 16S rDNA product 964 bp (90.9\%). On the other side, there were six isolates showed amplicons of average molecular size 486 bp (54.54\%) while two isolates amplified $1271 \mathrm{bp}$ (18.18\%), which targeted entFM and ces respectively as shown in Fig. 1.

\section{DISCUSSION}

Bacillus cereus is one of aerobic spore forming bacteria present everywhere, so can contaminate various food stuff resulting in food poisoning through existence of vegetative form or via production of toxins (Jessberger et al. 2019). The disease pathogenesis is influenced by different interacting factors; some are related to the pathogen itself and the other affected by the consumed foodstuffs as well as the intestinal microbiota (Jessberger et al. 2020).

There are abundant virulence factors produced by $B$. cereus strains resulting in the known two different forms which frequently self-limiting, but in some other conditions become serious and grave (EFSA 2005). These virulence factors are controlled and expressed by a group of master keys; Pleiotropic regulator (PlcR), a regulator of at least 45 genes responsible for virulence toxins and biofilm formation, Spo0A which a sporulation regulator, and CodY which is considered a key regulator of growth and survival of the organism (Ehling-Schulz et al. 2019).

In Egypt, the raw buffalo's milk is consumed on a broad scope, so there is a great concern to ensure its microbial quality for public health impact. This study was conducted to survey the subsistence of B. cereus among 85 buffalo's milk samples and declared eleven isolates with incidence of $12.94 \%$. Previous surveys exposed variation in isolation incidence; 4.6\% (Shehata et al. 1983), $66.6 \%$ (Sharma et al. 2003) and 26.66\% (Yusuf et al. 2018).

This high incidence may be attributed to many reasons comprising the widespread existence in the soil so be able to contaminate the used utensils or animal pasture and bedding as well as the possibility of milk adulteration by various cereal powders (Eneroth et al. 2001; Vidic et al. 2020). Moreover, the survival of spores for prolonged time in the intense processing of dehydrated foods and thus contaminate assorted foodstuffs through dehydrated ingredients (EFSA 2016).

The phenotypic characterization of obtained isolates was greatly similar to the picture of standard B. cereus strain. Commonly, there are variations in biochemical reactions and sugar fermentation response of $B$. cereus raw milk isolates. Our study revealed exposure of two predominant biotypes 2 ( 7 isolates) and 5 (3 isolates), these data was somewhat near other investigations (Hafeez et al. 2012; Yusuf et al. 2018).

The antibiotic susceptibility pattern of B. cereus isolates revealed that there was $100 \%$ resistance to penicillin $\mathrm{G}$ and amoxicillin. Conversely, all isolates were sensitive to gentamicin, neomycin and ciprofloxacin $(100 \%)$. The isolates response to other antibiotics was variable; less sensitive to tetracycline $(87.5 \%)$ vancomycin $(81.25 \%)$ and erythromycin (81.25\%), while showed intermediate sensitivity to both ampicillin $(56.25 \%)$ and polymyxin $(43.75 \%)$. These data coincided to those reported in many previous investigations; (OwusuKwarteng et al. 2017; Rana et al. 2020; Zhao et al. 2020). 
Int J Vet Sci, 2021, 10(3): 234-239.

Table 2: Multiplex PCR: Primers sequences, target genes, amplicon sizes and cycling conditions

\begin{tabular}{|c|c|c|c|c|c|c|c|c|}
\hline \multirow{2}{*}{$\begin{array}{l}\text { Target } \\
\text { gene }\end{array}$} & \multirow[t]{2}{*}{ Primers sequences } & \multirow{2}{*}{\multicolumn{2}{|c|}{$\begin{array}{l}\text { Amplified Primary } \\
\text { segment denaturation } \\
\text { (bp) }\end{array}$}} & \multicolumn{3}{|c|}{ Amplification (30 cycles) } & \multirow{2}{*}{\multicolumn{2}{|c|}{$\begin{array}{l}\text { Final References } \\
\text { extension }\end{array}$}} \\
\hline & & & & $\begin{array}{c}\text { 2ry } \\
\text { denaturation }\end{array}$ & Annealing & xtension & & \\
\hline \multirow{6}{*}{$\begin{array}{l}16 S \\
r D N A \\
\text { entFM } \\
486 \\
\text { Ces }\end{array}$} & GGATTAAGAGCTTGCTCTTAT & 964 & $94^{\circ} \mathrm{C} 5 \mathrm{~min}$ & $94^{\circ} \mathrm{C} 1 \mathrm{~min}$ & $50^{\circ} \mathrm{C} 1 \mathrm{~min}$ & $72^{\circ} \mathrm{C}$ & $72^{\circ} \mathrm{C}$ & \multirow{6}{*}{$\begin{array}{l}\text { Wehrle et al. } \\
\text { (2009); } \\
\text { Dzieciol et } \\
\text { al. (2013) }\end{array}$} \\
\hline & GATTGAGAGCTTGCTCTCAA & & & & & $1 \mathrm{~min}$ & $10 \mathrm{~min}$ & \\
\hline & GTTCGTTCAGGTGCTGGTAC & 486 & & & & & & \\
\hline & AGCTGGGCCTGTACGTACTT & & & & & & & \\
\hline & GGTGACACATTATCATATAAGGTG & 1271 & & & & & & \\
\hline & GTAAGCGAACCTGTCTGTAACAACA & & & & & & & \\
\hline
\end{tabular}

The resistance of $B$. cereus group species to $\beta$-lactam antibiotics is well established and is attributed to synthesis of B-lactamase enzyme, in the same time the variable resistance degrees of the organism to other antibiotics were mentioned (Abraha et al. 2017; Yu et al. 2019). The multidrug resistance phenomenon is put in mind and considered as public health significance due to the issues of therapy failure as well as control of foodborne illnesses (EFSA 2016).

The multiplex PCR analysis of structural16S rDNA was performed on the eleven isolates and the data revealed that only ten isolates amplified the targeted molecular weight of $964 \mathrm{bp}$. This given result may be attributed to that the negative eleventh isolate is seemed to be belonged to Bacillus thuringiensis; another member of B. cereus group which may show similarity in morphological and biochemical criteria but can be differentiated via molecular identification (Chen and Tsen 2002; Caamaño-Antelo et al. 2015; Sonmez and Erbas 2017; Fei et al. 2019).

Foodborne illnesses induced by $B$. cereus can be assorted into diarrheal and emetic syndromes (Stenfors Arnesen et al. 2008), which in majority of cases, the disease course is mild and self-limiting. Occasionally, the illness behavior goes badly resulting in more severe conditions and may lead to deaths (Naranjo et al. 2011). The B. cereus food poisoning (vomiting and/or diarrhea) is attributed to presence of various types of toxins expressed by certain genes.

The multiplex PCR was conducted on $B$. cereus isolates for screening of two genes encoding virulence's toxins; emetic toxin 'cereulide' (ces) as well as an enterotoxin (entFM). Our results revealed that six isolates carried entFM (54.54\%) while only two isolates harbored ces gene (18.18\%) (Fig. 2). Similar data of high prevalence of entFM gene and low incidence of ces among $B$. cereus isolates from dairy products have previously been mentioned in numerous investigations (Kim et al. 2010; Chaves et al. 2012; Yim et al. 2015 and Zhao et al. 2020).

\section{Conclusion}

Contracting from this investigation, the raw buffalo's milk declared a significant isolation ratio of $B$. cereus organism which showed a pattern of multidrug resistance and harbored some toxigenic virulence genes. Consequently, it was proposed that raw buffalo's milk may be a source of $B$. cereus food-borne public health concern. The discrimination of pathogenic B. cereus from other morphologically and biochemically similar nonpathogenic Bacillus species can be achieved through molecular base.

\section{Authors Contributions}

HAA has made the experimental design, collected the milk samples, and prepared the initial draft of this manuscript. EAK and HSM isolated the organism and performed the biochemical identification. DDK performed the antibiotic susceptibility test. All authors participated in DNA extraction and PCR run. All authors have approved final version of the manuscript.

\section{REFERENCES}

Abdou MA, Awny NM and Abozeid AAEM, 2011. Prevalence of toxicogenic bacteria in some foods and detection of Bacillus cereus and Staphylococcus aureus enterotoxin genes using multiplex PCR. Annals of Microbiology 62: 569-580. https://doi.org /10.1007/s13213-011-0293-7

Abraha A, Bikila T, Alemu S and Y Muktar, 2017. Bacillus Cereus isolation and load from raw cow milk sold in markets of Haramaya District, eastern Ethiopia. International Journal of Food Contamination 4: 15. https://doi.org/10.1186/s40550-017-0060-z

Al-Gamal MS, Ibrahim GA, Sharaf OM, Radwan AA, Dabiza NM, Youssef AM, El-ssayad MF, 2019. The protective potential of selected lactic acid bacteria against the most common contaminants in various types of cheese in Egypt. Heliyon 5: e01362. https://doi.org/10.1016/j.heliyon.2019. e01362

Caamaño-Antelo S, Fernández-No IC, Böhme K, Ezzat-Alnakip M, Quintela-Baluja M, Barros-Velázquez J and Calo-Mata $\mathrm{P}, 2015$. Genetic discrimination of foodborne pathogenic and spoilage Bacillus spp. based on three housekeeping genes. Food Microbiology 46: 288-298. https://doi.org/ 10.1016/j.fm.2014.08.013

Chaves JQ, Cavados CG and Vivoni AM, 2012. Molecular and toxigenic characterization of Bacillus cereus and Bacillus thuringiensis strains isolated from commercial ground roasted coffee. Journal of Food Protection 75: 518-22. https://doi.org/10.4315/0362-028X.JFP-11-325

Chen ML and Tsen HY, 2002, Discrimination of Bacillus cereus and Bacillus thuringiensis with $16 \mathrm{~S}$ rRNA and gyrB gene based PCR primers and sequencing of their annealing sites. Journal of Applied Microbiology 92: 912-919. https://doi.org/10.1046/j.1365-2672.2002.01606.x

Clinical Laboratory Standards Institute, 2015. Performance Standards for Antimicrobial Disk Susceptibility Tests; Approved Standards - Twelfth Edition, M02-A12.

CLSI, 2018. Performance Standards for Antimicrobial Suscebility Testing $-28^{\text {th }}$ Ed, Clinical Laboratory Standards Institute, M100-S28.

Dzieciol M, Fricker M, Wagner M, Hein I and Ehling-Schulz AM, 2013. A novel diagnostic real-time PCR assay for quantification and differentiation of emetic and nonemetic Bacillus cereus. Food Control 32: 176-185. https://doi.org/10.1016/j.foodcont.2012.11.010

EFSA, 2005. Opinion of the Scientific Panel on Biological Hazards on Bacillus cereus and other Bacillus spp in 
foodstuffs. EFSA Journal 175: 1-48. https://doi.org/ $\underline{10.2903 / \text { j.efsa. } 2005.175}$

EFSA 2016. Risks for public health related to the presence of Bacillus cereus and other Bacillus spp. including Bacillus thuringiensis in foodstuffs. EFSA Journal 14: 4524. https://doi.org/10.2903/j.efsa.2016.4524

Ehling-Schulz M, Lereclus D and Koehler TM, 2019. The Bacillus cereus Group: Bacillus Species with Pathogenic Potential. In: Gram-Positive Pathogens. 3rd Ed. In: Fischetti VA, Novick RP, Ferretti JJ, Portnoy DA, Braunstein M and Rood JI (eds). Wiley Online Library, pp: 875-902. https://doi.org/10.1128/microbiolspec.GPP30032-2018

Eneroth A, Svensson B, Molin G and Christiansson A, 2001, Contamination of pasteurized milk by Bacillus cereus in the filling machine. Journal of Dairy Research 68: 189-196. https://doi.org/10.1017/s002202990100485x

Fei P, Yuan X, Zhao S, Yang T, Xiang J, Xi C, Zhou L and Ji M, 2019. Prevalence and Genetic Diversity of Bacillus cereus Isolated from Raw Milk and Cattle Farm Environments. Current Microbiology 76: 1355-1360. https://doi.org/10.1007/s00284-019-01741-5

Forghani F, Singh P, Seo KH, and Oh DH, 2016. A novel pentaplex real time (RT) -PCR high resolution melt curve assay for simultaneous detection of emetic and enterotoxin producing Bacillus cereus in food. Food Control 60: 560 568. https://doi.org/10.1016/j.foodcont.2015.08.030

Giffel MC, Beumer RR, Klijn N, Wagendorp A and Rombouts FM, 1997. Discrimination between Bacillus cereus and Bacillus thuringiensis using specific DNA probes based on variable regions of 16S rRNA. FEMS Microbiology Letters 146: 47-51. https://doi.org/10.1111/j.15746968.1997.tb101 69.X

Hafeez Y, Iqbal A and Ahmad M, 2012. Biotyping of Bacillus cereus from the street vended foods in Srinagar area of Kashmir, India. Veterinary World 5: 590-593. https://doi.org/10.5455/veworld.2012.590-593

Haque MA, Quan H, Zuo Z, Khan A, Siddique N and He C, 2021. Pathogenicity of feed-borne Bacillus cereus and its implication on food safety. Agrobiological Records 3: 1-16. https://doi.org/10.47278/journal.abr/2020.015

Hussain MS, Kwon M, Tango CN and OH DH, 2018. Effect of electrolyzed water on the disinfection of Bacillus cereus biofilms: The mechanism of enhanced resistance of sessile cells in the biofilm matrix. Journal of Food Protection 81: 860-869. https://doi.org/10.4315/0362-028x.jfp-17-450

Jessberger N, Dietrich R, Granum PE and Märtlbauer E, 2020. The Bacillus cereus Food Infection as Multifactorial Process. Toxins (Basel) 12: 701. https://doi.org/10.3390/ toxins 12110701

Jessberger N, Kranzler M, Da Riol C, Schwenk V, Buchacher T, Dietrich R, Ehling-Schulz M and Märtlbauer E, 2019. Assessing the toxic potential of enteropathogenic Bacillus cereus. Food Microbiol 84: 103276. https://doi.org/10.1016 /j.fm.2019.103276

Jeßberger N, Rademacher C, Krey VM, Dietrich R, Mohr AK, Bohm ME, Scherer S, Ehling-Schulz M and Märtlbauer E, 2017. Simulating intestinal growth conditions enhances toxin production of enteropathogenic Bacillus cereus. Frontiers in Microbiology 8: 627. https://doi.org/10.3389/ fmicb.2017.00627

Jha NK and Narayan KG, 1995. Biotyping of Bacillus cereus isolates. Journal of Food Science and Technology 32: 231232.

Kim JB, Kim JM, Kim SY, Kim JH, Park YB, Choi NJ and Oh $\mathrm{DH}, 2010$. Comparison of enterotoxin production and phenotypic characteristics between emetic and enterotoxic Bacillus cereus. Journal of Food Protection 73: 1219-1224. https://doi.org/10.4315/0362-028x-73.7.1219
Kranzler M, Stollewerk K, Rouzeau-Szynalski K, Blayo L, Sulyok M and EhlingSchulz M, 2016.Temperature exerts control of Bacillus cereus emetic toxin production on posttranscriptional levels. Frontiers in Microbiology 7: 1640. https://doi.org/10.3389/ fmicb.2016.01640

Kumari S and Sarkar PK, 2016. Bacillus cereus hazard and control in industrial dairy processing environment. Food Control 69: 20-29. https://doi.org/10.1016/j.foodcont.2016. $\underline{04.012}$

Liu XY, Hu Q, Xu F, Ding SY, Zhu K, 2020. Characterization of Bacillus cereus in dairy products in China. Toxins (Basel). 12: 454. https://doi.org/10.3390/toxins12070454

Lucking G, Stoeckel M, Atamer Z, Hinrichs J and Ehling-Schulz M, 2013. Characterization of aerobic spore-forming bacteria associated with industrial dairy processing environments and product spoilage. International Journal of Food Microbiology 166: 270-279. https://doi.org/10.1016/j. ijfoodmicro.2013.07.004

Majed R, Faille C, Kallassy M and Gohar M, 2016. Bacillus cereus biofilms - Same, only different. Frontiers in Microbiology 7: 1054. https://doi.org/10.3389/fmicb.2016. $\underline{01054}$

Mousa SA and AA Marwan, 2019. Growth performance, rumen fermentation and selected biochemical indices in buffalo calves fed on Basillis subtilus supplemented diet International Journal of Veterinary Science 8: 151-156.

Naranjo M, Denayer S, Botteldoorn N, Delbrassinne L, Veys J, et al. 2011. Sudden death of a young adult associated with Bacillus cereus food poisoning. Journal of Clinical Microbiology 49: 4379-4381. https://doi.org/10.1128/JCM. 05129-11

Osimani A, Aquilanti L and Clementi F, 2018. Bacillus cereus foodborne outbreaks in mass catering. International Journal of Hospitality Management 72: 145-153. https://doi.org/ $\underline{10.1016 / j . i j h m .2018 .01 .013}$

Owusu-Kwarteng J, Wuni A, Akabanda F, Tano-Debrah K and Jespersen L, 2017. Prevalence, virulence factor genes and antibiotic resistance of Bacillus cereus sensu lato isolated from dairy farms and traditional dairy products. BMC Microbiology 17: 65. https://doi.org/10.1186/s12866-017$\underline{0975-9}$

Rana N, Panda AK, Pathak N, Gupta T and Thakur SD, 2020. Bacillus cereus: public health burden associated with readyto-eat foods in Himachal Pradesh, India. Journal of Food Science and Technology 57: 2293-2302. https://doi.org/ 10.1007/s13197-020-04267-y

Rhodehamel, EJ and Harmon SM, 2001. Bacillus cereus. In: Jackson GJ, Merker RI, Bandler R, editors. Bacteriological Analytical Manual, Centre for food safety and Applied Nutrition, US Food and Drug Administration, College Park, MD, USA

Sadek ZI, Abdel-Rahman MA, Azab MS, Darwesh OM and Hassan MS, 2018. Microbiological evaluation of infant foods quality and molecular detection of Bacillus cereus toxins relating genes Toxicology Reports 5: 871-877. https://doi.org/10.1016/j.toxrep.2018.08.013

Sambrook J, Fritsch EF and Maniatis T, 1989. Purification of closed circular DNA by equilibrium centrifugation in CsClethidium bromide gradients. In: Molecular Cloning: A Laboratory Manual, New York, CSH Laboratory.

Sharma CS, Sharma DK, Gill JPS, Aulakh RS and Sharma JK, 2003. Bacillus cereus from foods of animal origin in India and its public health significance. Acta Veterinaria Scandinavica 44: 118. https://doi.org/10.1186/1751-014744-S1-P118

Shehata AE, Magdoub MNI, Nagwa ES, and El-Samragy YA, 1983. Aerobic mesophilic and psychrotrophic sporeforming bacteria in buffalo milk. Journal of Dairy Science 66: 12281231. https://doi.org/10.3168/jds.S0022-0302(83)81927-4 
Int J Vet Sci, 2021, 10(3): 234-239.

Sonmez M and Erbas G, 2017. Isolation and identification of Candida spp. from mastitic cattle milk and determination of antifungal susceptibilities. International Journal of Veterinary Science 6: 104-107.

Stenfors Arnesen LP, Fagerlund A and Granum PE. 2008. From soil to gut: Bacillus cereus and its food poisoning toxins. FEMS Microbiology Reviews 32: 579-606. https://doi.org/10.1111/j.1574-6976.2008.00112.x

Vidic J, Chaix C, Manzano M and Heyndrickx M, 2020. Food Sensing: Detection of Bacillus cereus Spores in Dairy Products. Biosensors (Basel) 10: 15. https://doi.org/ $\underline{10.3390 / \mathrm{bios} 10030015}$

Wehrle E, Moravek M, Dietrich R, Bürk C, Didier A and Märtlbauer E, 2009. Comparison of multiplex PCR, enzyme immunoassay and cell culture methods for the detection of enterotoxinogenic Bacillus cereus. Journal of Microbiological Methods 78: 265-270. https://doi.org/ 10.1016/j.mimet.2009.06.013

Yim JH, Kim KY, Chon JW, Kim DH, Kim HS, Choi DS, Choi IS and Seo KH, 2015. Incidence, Antibiotic Susceptibility, and Toxin Profiles of Bacillus cereus sensu lato Isolated from Korean Fermented Soybean Products. Journal of Food Science 80: M1266-70. https://doi.org/10.1111/1750$\underline{3841.12872}$

Yu P, Yu S, Wang J, Guo H, Zhang Y, Liao X, Zhang J, Wu S, Gu Q, Xue L, Zeng H, Pang R, Lei T, Zhang J, Wu Q and Ding Y, 2019. Bacillus cereus isolated from vegetables in china: incidence, genetic diversity, virulence genes, and antimicrobial resistance. Frontiers in Microbiology 10: 948. https://doi.org/10.3389/fmicb.2019.00948

Yusuf U, Kotwal SK, Gupta S and Ahmed T, 2018. Identification and antibiogram pattern of Bacillus cereus from the milk and milk products in and around Jammu region. Veterinary World 11: 186-191. https://doi.org/ 10.14202/vetworld. 2018.186-191

Zhao S, Chen J, Fei P, Feng H, Wang Y, Ali MA, Li S, Jing H and Yang W, 2020. Prevalence, molecular characterization, and antibiotic susceptibility of Bacillus cereus isolated from dairy products in China. Journal of Dairy Science 103: 3994-4001. https://doi.org/ 10.3168/jds.2019-17541 